\title{
Effect of diets with different contents of sunflower meal without or with exogenous enzymes supplementation on gastrointestinal tract response of growing turkeys
}

\author{
J. Juśkiewicz ${ }^{1,4}$, J. Jankowski ${ }^{2}$, A. Lecewicz ${ }^{2}$, B. Slominski ${ }^{3}$ \\ and Z. Zduńczyk ${ }^{1}$ \\ 'Institute of Animal Reproduction and Food Research, \\ Polish Academy of Sciences \\ Tuwima 10, 10-747 Olsztyn, Poland \\ 'University of Warmia and Mazury, Department of Poultry Science \\ 10-718 Olsztyn, Poland \\ ${ }^{3}$ University of Manitoba, Department of Animal Science \\ Fort Garry Campus 12, Dafoe Road 201, Winnipeg, Manitoba, Canada
}

(Received 29 March 2010; revised version 29 July 2010; accepted 16 August 2010)

\begin{abstract}
The present experiment was conducted to investigate the effect of a different dietary content of sunflower meal (SFM) and the efficiency of an non-starch polysaccharide (NSP)-degrading enzyme preparation on growth and gut function of young turkeys. A total of 1512 one-day-old male turkey poults were randomly assigned to 8 dietary treatments, with 7 pens per treatment and 27 birds per pen. Experimental diets with a different content of SFM $(0,7,14$ and $21 \%$; SFM, $\mathrm{SFM}_{7}, \mathrm{SFM}_{14}$ and $\mathrm{SFM}_{21}$ groups, respectively) were administered in two variants, with and without NSP-degrading enzymes ( $\mathrm{E}+$ and $\mathrm{E}_{0}$ treatments, respectively). Diets fed to the turkeys for 8 weeks were isonitrogenous and isocaloric, but they differed substantially with regard to crude fibre content (in average 2.98, 3.97, 4.64 and 5.64\% in the $\mathrm{SFM}_{0}, \mathrm{SFM}_{7}, \mathrm{SFM}_{14}$ and $\mathrm{SFM}_{21}$ groups, respectively). The enzyme preparation applied to a diet caused a tendency towards lower ileal viscosity $(\mathrm{P}=0.099)$ and a significant decrease in caecal total volatile fatty acids concentration,
\end{abstract}

\footnotetext{
* Supported by the State Committee for Scientific Rescarch, Grant No. 31105831

${ }^{4}$ Corresponding author: e-mail; j.juskiewicz@pan.olsztyn.pl
} 
despite of the observed increase in activities of bacterial $\alpha$-glucosidase, $\alpha$-galactosidase and $\beta$-galactosidase in the E+treatment. At the same time, two-way ANOVA revealed that following the dietary inclusion of SFM at the amount of 14 and $21 \%$, a significant decrease was observed in final body weight, small intestine and caccal tissue mass, caccal digesta mass, as well as the rate of bacterial production of volatile fatty acids in the caeca. Such an effect was not recorded when SFM was applied at a dose of $7 \%$. In conclusion, sunflower meal rich in crude fibre added at the level of $14-21 \%$ to a diet for growing turkeys may induce undesirable processes manifested in the decrease in relative mass of small intestine and caecal tissues, as well as potent inhibition of the fermentation processes in the caeca. Our study showed additionally that high fibre sunflower meal could be used at a dose of up to $7 \%$ without any adverse effects on the gastrointestinal physiology of the growing turkeys.

KEY WORDS: sunflower meal, gastrointestinal tract, caecal fermentation, turkey

\section{INTRODUCTION}

Soyabean meal (SBM) has been reported to presumably be the only common protein supplement that is typically included in poultry rations with no limitation as to the quantity used (Bach Knudsen, 2001). In contrast, other studies have shown that dietary SBM added at a high level may lead to a decrease in intestinal absorptive surface area and an undesirable increase in litter moisture concentration in young turkeys due to relatively high amounts of raffinose family oligosaccharides (Juśkiewicz et al., 2009). Having in mind that effect as well as the fact that protein is often one of the most expensive components of poultry diets, nutritionists have started a search for alternative ingredients which have potential as cost-effective protein sources, sometimes underutilized in poultry production (Mushtaq et al., 2006). It is well known that sunflower oil is considered one of the most healthful vegetable oils for humans, thus the availability of sunflower meal (SFM), as a by-product, is relatively high (Vieira et al., 1992; Stodolak et al., 2009). SFM obtained from processed intact sunflower seeds is rich in protein but also has a high content of fibre. Moreover, diets formulated with SFM can be deficient in lysine. The latter could be overcome by an appropriate supplementation. But high level of fibre, causing low dietary energy values, may excessively reduce the time of feed passage throughout the digestive system and diminish nutrients utilization (Wenk, 2001). Among poultry, turkeys seem to be most sensitive to a high content of crude fibre in a diet. Experiments concerning SFM in turkeys' feeding are sparse, thus the recommended level of dietary SFM for growing turkeys have not been explicitly established. Moreover, studies focused not only on the growth and performance response but with a deeper look into physiology have increasingly been in great demand. In the light of the above, the aim of this study was to investigate the growth and the physiological response of the gastrointestinal tract 
of young turkeys (to 8 wk of age) to diets with different contents of sunflower meal, applied without or with NSP-degrading enzymes. As the experimental diets differed substantially in non-digestible carbohydrate fractions, great attention was paid to the development and bacterial fermentation processes in the caeca of the birds.

\section{MATERIAL AND METHODS}

\section{Birds and housing}

The experimental procedure was approved by the Local Ethics Committee. The study was conducted at the research laboratory of the Department of Poultry Science, University of Warmia and Mazury in Olsztyn. The experimental materials comprised a total of 1512 heavy-type Big 6 turkeys purchased as one-day-old male poults at the "Grelavi" Hatchery in Kętrzyn. The birds were randomly assigned to 8 dietary treatments, with 7 pens per treatment and 27 birds per pen, and they were raised on deep litter. At the end of 8-wk period, birds were weighed, and feed consumption was recorded. Weight gain and feed efficiency were calculated. For performance indices, each pen was considered an experimental unit. Light was provided for $16 \mathrm{~h}$ per day. Indoor temperature was $32^{\circ} \mathrm{C}$ at the beginning of the experiment and $22^{\circ} \mathrm{C}$ at the end of week 8 . At the beginning of the study, poults were administered Aviffa-RTI - live vaccine against infectious rhinotracheitis. During two rearing periods (weeks 1-4 and $5-8$ ), birds were fed isoenergetic diets containing 28 and $26 \%$ crude protein, respectively, covering turkeys nutrient requirement of (NRC, 1994). They had frec access to feed and water.

Diets

Commercially available soyabean (from a local feed company) and sunflower (from WIOJL-AGRO Co., Winnica, Ukraine) meals were used in this experiment. The composition of experimental diets with a different content of SFM $(0,7$, 14 and $21 \%$ ) is given in Table 1 . The levels of other components, including SBM, were determined so as to meet the nutrient requirement of turkeys (NRC, 1994) aged 1-4 and 5-8 weeks. Each diet was prepared in two variants, with and without non-starch polysaccharide (NSP)-degrading enzymes. The enzymatic preparation supplied, U: pectinase 500 , cellulose $40 \mathrm{U}$, xylanase 1600 , glucanase 800 , mannanase 200, galactanase 20 , and other minor enzymes per $\mathrm{kg}$ diet (Superzyme CS, Canadian Bio-Systems Inc., Calgary, AB, Canada). The lysine, arginine, methionine, threonine, tryptophan, mineral and vitamin contents were 
similar in all dietary treatments. The average content of crude fibre in the diets was approximately $2.98,3.97,4.64$ and 5.64 in the $\mathrm{SFM}_{0}, \mathrm{SFM}_{7}, \mathrm{SFM}_{14}$ and $\mathrm{SFM}_{21}$ groups, respectively. In terms of total NSP the aforementioned diets contained approximately $11.17,11.93,12.68$ and 13.43 of total NSP, respectively.

Table 1. Composition of experimental diets

\begin{tabular}{|c|c|c|c|c|c|c|c|c|}
\hline & \multicolumn{4}{|c|}{ Period of feeding 1-4 weeks } & \multicolumn{4}{|c|}{ Period of feeding 5-8 weeks } \\
\hline & $\mathrm{SFM}_{0}$ & $\mathrm{SFM}_{7}$ & $\mathrm{SFM}_{14}$ & $\mathrm{SFM}_{21}$ & $\mathrm{SFM}_{0}$ & $\mathrm{SFM}_{7}$ & $\mathrm{SFM}_{14}$ & $\mathrm{SFM}_{21}$ \\
\hline \multicolumn{9}{|l|}{ Ingredient, $\mathrm{g} / \mathrm{kg}$} \\
\hline wheat & 245.8 & 211.9 & 178.5 & 144.3 & 244.9 & 207.9 & 171.0 & 134.0 \\
\hline maize & 200.0 & 200.0 & 200.0 & 200.0 & 200.0 & 200.0 & 200.0 & 200.0 \\
\hline soy & 433.0 & 384.0 & 335.0 & 286.0 & 471.5 & 424.5 & 377.4 & 330.2 \\
\hline 1 (SFM) & - & 70.0 & 140.0 & 210.0 & - & 70.0 & 140.0 & 210.0 \\
\hline & 50.0 & 50.0 & 50.0 & 50.0 & - & - & - & - \\
\hline al fat $(1: 1)$ & 24.5 & 37.5 & 50.0 & 63.0 & 25.5 & 59.1 & 72.7 & 86.3 \\
\hline sodiun & 1.5 & 1.5 & 1.5 & 1.5 & 1.5 & 1.5 & 1.5 & 1.5 \\
\hline & 2.6 & 2.6 & 2.6 & 2.6 & 2.1 & 2.1 & 2.2 & 2.2 \\
\hline & 18.0 & 17.5 & 17.0 & 16.7 & 14.4 & 14.1 & 13.7 & 13.4 \\
\hline & 20.0 & 20.0 & 20.0 & 20.0 & 14.8 & 14.9 & 15.1 & 15.2 \\
\hline & 1.7 & 1.5 & 1.3 & 1.1 & 1.5 & 1.4 & 1.2 & 1.1 \\
\hline & 0.4 & 1.0 & 1.6 & 2.3 & 1.3 & 2.0 & 2.7 & 3.4 \\
\hline & - & - & - & - & - & - & 0.1 & 0.2 \\
\hline mineral and vitamin premix ${ }^{1}$ & 2.5 & 2.5 & 2.5 & 2.5 & 2.5 & 2.5 & 2.5 & 2.5 \\
\hline \multicolumn{9}{|l|}{ Calculated composition, $\mathrm{g} / \mathrm{kg}$} \\
\hline & 279.9 & 280.0 & 280.1 & 279.8 & 260.0 & 260.0 & 260.0 & 260.0 \\
\hline & 12.1 & 12.1 & 12.0 & 12.0 & 10.0 & 10.0 & 10.0 & 10.0 \\
\hline & 8.8 & 8.6 & 8.4 & 8.2 & 5.0 & 5.0 & 5.0 & 5.0 \\
\hline & 16.0 & 16.0 & 16.0 & 16.0 & 15.0 & 15.0 & 15.0 & 15.0 \\
\hline methionine & 6.0 & 6.0 & 6.0 & 6.0 & 5.2 & 5.2 & 5.2 & 5.2 \\
\hline \multicolumn{9}{|l|}{ methionine + cystine } \\
\hline threonine & 11.0 & 10.9 & 10.9 & 10.9 & 9.6 & 9.5 & 9.5 & 9.5 \\
\hline & 17.8 & 18.2 & 18.6 & 18.9 & 17.2 & 17.4 & 17.6 & 17.8 \\
\hline & 3.6 & 3.6 & 3.6 & 3.6 & 3.3 & 3.3 & 3.2 & 3.2 \\
\hline & 1.7 & 1.7 & 1.7 & 1.7 & 1.5 & 1.5 & 1.5 & 1.5 \\
\hline crude fibre & 32.7 & 40.6 & 48.5 & 56.4 & 34.3 & 42.5 & 50.8 & 59.2 \\
\hline $\mathrm{ME}, \mathrm{MJ} / \mathrm{kg}$ & 11.72 & 11.72 & 11.71 & 11.71 & 12.14 & 12.14 & 12.14 & 12.14 \\
\hline \multicolumn{9}{|l|}{ Analysed composition, $\mathrm{g} / \mathrm{kg}$} \\
\hline & 275.0 & 282.2 & 280.4 & 281.3 & 262.4 & 265.8 & 267.6 & 272.5 \\
\hline & 28.8 & 42.5 & 46.1 & 55.5 & 30.7 & 36.9 & 46.7 & 57.2 \\
\hline non-starch polysaccharides & 108.3 & 115.8 & 123.3 & 130.7 & 115.1 & 122.7 & 130.3 & 137.8 \\
\hline & 141.0 & 151.2 & 164.4 & 171.5 & 148.5 & 158.5 & 168.8 & 178.9 \\
\hline ether extract & 48.0 & 56.3 & 70.1 & 80.5 & 69.7 & 77.9 & 90.8 & 106.7 \\
\hline
\end{tabular}

${ }^{1}$ for 1 to 4 and 5 to 8 week of feeding the vitamin and mineral premix supplied per kg of diet, IU: vit. A 15.000 , and 13.000; mg: vit. E 40 and 35, respectively. For 1 to 8 week of feeding the vitamins and mineral premix supplied per kg of diet, mg: Se 0.3, Mn 150, Zn 90, Fe 60, Cu 15, I 1, diclazuril 1, IU: vit. $D_{3} 4,500$; $\mathrm{mg}$ : vit $\mathrm{K}_{3} 2.5$, thiamin 3.5 , riboflavin 10 , vit. $\mathrm{B}_{6} 6$, vit $\mathrm{B}_{12} 0.03$, folic acid 2, biotin 0.36 , niacin 75 , pantothenic acid 21 , choline 600 
For chemical analysis, the samples were ground to pass through a $0.5 \mathrm{~mm}$ sieve. Feed ingredient, diet or digesta samples were analysed in duplicate for dry matter, crude protein (CP), fat, and crude fibre (CF) using AOAC (2005) methods 934.01, 976.05, 920.39 and 978.10, respectively. NSP were determined by gasliquid chromatography using the procedure described by Slominski and Campbell (1990). Briefly, $100 \mathrm{mg}$ samples were boiled with $2 \mathrm{ml}$ dimethylsulphoxide for $1 \mathrm{~h}$ and then incubated at $45^{\circ} \mathrm{C}$ overnight with a sodium acetate buffer solution (pH 5.2) of starch-degrading enzymes: amylase, pullulanase and amyloglucosidase (Sigma Chemical Co., St Louis, MO). Ethanol was then added and the mixture was left for $1 \mathrm{~h}$ at room temperature before being centrifuged at $1990 \mathrm{~g}$, for $10 \mathrm{~min}$ at $21^{\circ} \mathrm{C}$. The supernatant was discarded and the dried residue was dissolved in $1 \mathrm{ml}$ of $12 \mathrm{M}$ sulphuric acid and incubated for $1 \mathrm{~h}$ at $35^{\circ} \mathrm{C}$. Six ml of water and $5 \mathrm{ml}$ of myoinositol (internal standard) solution were then added and the mixture was boiled for $2 \mathrm{~h}$. One $\mathrm{ml}$ of the hydrolysate was taken and neutralized with 12 $\mathrm{M}$ ammonium hydroxide, reduced with sodium borohydride, and acetylated with acetate anhydride in the presence of 1 -methylimidazole. Component sugars were separated using a SP-2340 column and a Varian CP 3380 Gas Chromatograph (Varian Canada Inc., Mississauga, Ontario, Canada).

\section{Sample collection and chemical analyses}

After 8 weeks of feeding, 10 turkeys that represented an average body weight for each group were killed by cervical dislocation. After laparatomy, segments of the digestive tract (crop, ventriculus, small intestine, caeca and colon) were removed and weighed. As soon as possible after euthanasia (about $20 \mathrm{~min}$ ) $\mathrm{pH}$ was measured in each segment using a microelectrode and $\mathrm{pH} / \mathrm{ION}$ meter (model 301, Hanna Instruments, Vila do Conde, Portugal). Samples of ileal (middle, 1/3 section of ileum) and caecal contents were used for immediate analysis (ammonia, dry matter, viscosity, volatile fatty acids - VFA), while the rest of the caecal digesta was transferred to tubes and stored at $-70^{\circ} \mathrm{C}$. The ventriculus (gizzard), small intestine, caeca and colon were flushed with water, blotted on filter paper and weighed as the tissue mass.

Dry matter of digesta was determined at $105^{\circ} \mathrm{C}$. The total contents of the small intestine were collected, mixed on a vortex, and centrifuged at $7.211 \mathrm{~g}$ for $10 \mathrm{~min}$. The supernatant fraction $(0.5 \mathrm{ml})$ was placed in a Brookfield LVDVII+cone-plate rotational viscometer (CP40; Brookfield Engineering Laboratories Inc., Stoughton, MA, USA) and the viscosity of all samples was measured at a fixed temperature of $39^{\circ} \mathrm{C}$ and at a shear rate of 60 per min. The viscosity value was recorded as an apparent viscosity. In fresh caecal digesta, ammonia was extracted, trapped in a solution of boric acid in the Conway's dishes, and determined by 
direct titration with sulphuric acid (Hofirek and Haas, 2001).

Caecal digesta samples were subjected to VFA analysis using gas chromatography (Shimadzu GC-2010, Shimadzu, Kyoto, Japan). The samples $(0.2 \mathrm{~g})$ were mixed with $0.2 \mathrm{ml}$ formic acid, diluted with deionized water and centrifuged at $7.211 \mathrm{~g}$ for $10 \mathrm{~min}$. The supernatant was loaded onto a capillary column (SGE BP $21.30 \mathrm{~m} \times 0.53 \mathrm{~mm}$ ) using an on-column injector. The initial oven temperature was $85^{\circ} \mathrm{C}$ and was raised to $180^{\circ} \mathrm{C}$ by $8^{\circ} \mathrm{C} / \mathrm{min}$ and held there for $3 \mathrm{~min}$. The temperatures of flame ionization detector and the injection port were 180 and $85^{\circ} \mathrm{C}$, respectively. The sample volume for $\mathrm{GC}$ analysis was $1 \mu \mathrm{l}$. Caecal VFA pool size was calculated as the sum of VFA concentration in digesta and caecal digesta mass.

The bacterial glycolytic activity in the caecal digesta was measured by the rate of $\rho$ - or $o$-nitrophenol release from their nitrophenylglucosides according to the modified method of Djouzi and Andrieux described by Juśkiewicz et al. (2006). The following substrates were used: $\rho$-nitro-phenyl- $\alpha$-Dglucopyranoside (for $\alpha$-glucosidase), and $\rho$-nitrophenyl- $\beta$-D-glucopyranoside (for $\beta$-glucosidase), $\rho$-nitrophenyl- $\alpha$-D-galactopyranoside( $\alpha$-galactosidase), $o$-nitrophenyl$\beta$-D-galactopyranoside ( $\beta$-galactosidase), and $\rho$-nitrophenyl- $\beta$-D-glucuronide (for $\beta$-glucuronidase). The reaction mixture contained $0.3 \mathrm{ml}$ of a substrate solution $(5 \mathrm{mM})$ and $0.2 \mathrm{ml}$ of a $1: 10(\mathrm{v} / \mathrm{v})$ dilution of the caecal sample in $100 \mathrm{mM}$ phosphate buffer ( $\mathrm{pH} 7.0$ ) after centrifugation at $7.211 \mathrm{~g}$ for $15 \mathrm{~min}$. Incubation was carried out at $37^{\circ} \mathrm{C}$ and $\rho$-nitrophenol was quantified at $400 \mathrm{~nm}$ and at $420 \mathrm{~nm}$ (o-nitrophenol concentration) after the addition of $2.5 \mathrm{ml}$ of $0.25 \mathrm{M}$ cold sodium carbonate. The enzymatic activity ( $\alpha$ - and $\beta$-glucosidase, $\alpha$ - and $\beta$-galactosidase, and $\beta$-glucuronidase) was expressed as $\mu \mathrm{mol}$ product formed per min (IU) per g of digesta.

\section{Statistical analysis}

The STATISTICA software package version 8.0 (StatSoft Corp., Krakow, Poland) was used to determine if variables differed among treatment groups. Twoway ANOVA was performed to assess the effects of the dietary level of sunflower meal $(0,7,14$ and $21 \%$ ), of dietary addition of enzyme mixture preparation (without and with supplementation) and of the interaction between SFM level and NSP-degrading enzyme addition $(\mathrm{D} \times \mathrm{E})$ (Snedecor and Cochran, 1989). When the ANOVA indicated significant treatment effects, means were separated using Duncan's multiple range test. In the Tables, results are presented as mean values with pooled standard errors. Data were checked for normality before statistical analysis was performed. Differences were considered to be significant at $\mathrm{P} \leq 0.05$. 


\section{RESULTS}

After 8 weeks, the body weights of turkeys fed diets containing 14 and $21 \%$ SFM were significantly lower, compared with the control group (Table 2). Moreover, the birds fed the diet containing $21 \%$ of SFM were also significantly lighter than those from the $\mathrm{SFM}_{7}$ treatment. A tendency $(\mathrm{P}=0.068)$ towards lower diet intake in SFM groups was observed during eight weeks of feeding. Neither SFM levels nor enzymatic supplementation affected the feed conversion ratio during the experimental period covering 8 weeks.

Table 2. The effect of different content of sunflower mcal' (SEM) in dicts on the growth performance of turkeys aged 8 weeks of age

\begin{tabular}{|c|c|c|c|}
\hline Dictary treatment & Diet intake, $\mathrm{kg}$ & Body weight, $\mathrm{kg}$ & Feed efficiency ratio \\
\hline \multicolumn{4}{|l|}{ Subgroup } \\
\hline $\mathrm{SFM}_{0} \mathrm{E}_{0}$ & 8.01 & 4.13 & 1.94 \\
\hline $\mathrm{SFM}_{0} \mathrm{E}+$ & 7.58 & 4.21 & 1.80 \\
\hline $\mathrm{SFM}_{7} \mathrm{E}_{0}$ & 7.64 & 4.11 & 1.86 \\
\hline $\mathrm{SFM}_{7} \mathrm{E}+$ & 7.58 & 4.14 & 1.83 \\
\hline $\operatorname{SFM}_{14} E_{0}$ & 7.22 & 4.01 & 1.80 \\
\hline $\mathrm{SFM}_{14} \mathrm{E}+$ & 7.60 & 4.02 & 1.89 \\
\hline $\mathrm{SFM}_{21} \mathrm{E}_{0}$ & 7.29 & 3.90 & 1.87 \\
\hline $\mathrm{SFM}_{21} \mathrm{E}^{+}$ & 7.40 & 3.96 & 1.95 \\
\hline $\mathrm{SEM}^{2}$ & 0.055 & 0.025 & 0.018 \\
\hline \multicolumn{4}{|l|}{$\operatorname{Diet}(D)$} \\
\hline $\mathrm{SFM}_{0}$ & 7.80 & $4.17^{\circ}$ & 1.87 \\
\hline $\mathrm{SFM}_{7}$ & 7.60 & $4.13^{\mathrm{ab}}$ & 1.84 \\
\hline $\mathrm{SFM}_{14}$ & 7.42 & $4.01^{\mathrm{be}}$ & 1.85 \\
\hline $\mathrm{SFM}_{21}$ & 7.51 & $3.93^{\mathrm{c}}$ & 1.91 \\
\hline$P$ value & 0.068 & 0.003 & 0.549 \\
\hline \multicolumn{4}{|c|}{ Enzymes mixtures $(E)$} \\
\hline $\mathrm{E}_{0}$ & 7.54 & 4.03 & 1.87 \\
\hline $\mathrm{E}+$ & 7.65 & 4.09 & 1.87 \\
\hline$P$ value & 0.276 & 0.304 & 0.938 \\
\hline Interaction $\mathrm{D} \times \mathrm{E}$ & 0.059 & 0.960 & 0.087 \\
\hline
\end{tabular}

'SFM was applied at following dietary levels: $0,7,14$ and $21 \%\left(\mathrm{SFM}_{0}, \mathrm{SFM}_{7}, \mathrm{SFM}_{14}\right.$ and $\mathrm{SFM}_{21}$ respectively); ${ }^{2}$ SEM - standard error of the mean (SD for all birds divided by the square root of turkey number); values within each column with the same superscript letter are not different at $\mathrm{P} \leq 0.05$

At 8 weeks of age, regardless of the addition of NSP-degrading enzymes, the inclusion of SFM to a diet caused a tendency towards lower ventriculus $\mathrm{pH}$ $(\mathrm{P}=0.069)$ and relative tissue mass $(\mathrm{P}=0.089)$, when compared to the control 
treatment without SFM addition (Table 3). The turkeys fed diets containing 14 and $21 \%$ SFM were characterized by a significantly lower small intestinal tissue weight than those fed the 0 and $7 \%$ SFM diets $(\mathrm{P}<0.05)$. Dietary SFM had no effect on ileal digesta $\mathrm{pH}$, dry matter concentration nor viscosity value $(\mathbf{P}<0.05)$. When diets supplementation with the enzyme preparation was taken into consideration, the effect of this additive on indices of upper gastrointestinal tract functioning was negligible, except numerically lower ileal viscosity (1.26 vs $1.36 \mathrm{mPa} \cdot \mathrm{s} ; \mathrm{P}=0.099$ ).

Table 3. Indices of upper GIT functioning in turkeys fed diets with increasing levels of sunflower meal' (SFM) without or with inclusion of feed enzymes (E)

\begin{tabular}{|c|c|c|c|c|c|c|c|}
\hline & \multirow{2}{*}{$\begin{array}{l}\text { Crop } \\
\text { pH of } \\
\text { digesta }\end{array}$} & \multicolumn{2}{|c|}{ Ventriculus } & \multicolumn{4}{|c|}{ Small intestine } \\
\hline & & $\begin{array}{l}\mathrm{pH} \text { of } \\
\text { digesta }\end{array}$ & $\begin{array}{c}\text { tissue, } \mathrm{g} / \mathrm{kg} \\
\text { BW }\end{array}$ & $\begin{array}{c}\mathrm{pH} \text { of ileal } \\
\text { digesta }\end{array}$ & $\begin{array}{l}\text { tissue } \\
\mathrm{g} / \mathrm{kg} \mathrm{BW}\end{array}$ & $\begin{array}{l}\text { dry matter } \\
\text { (ilcal), } \%\end{array}$ & $\begin{array}{r}\text { viscosity } \\
\text { (ileal), } \\
\text { mPa-s }\end{array}$ \\
\hline \multicolumn{8}{|l|}{ Subgrotup } \\
\hline $\mathrm{SFM}_{0} \mathrm{E}_{0}$ & 4.88 & 3.78 & 13.39 & 5.63 & 24.56 & 15.69 & 1.37 \\
\hline $\mathrm{SFM}_{0} \mathrm{E}+$ & 4.96 & 3.83 & 12.76 & 5.32 & 23.71 & 16.55 & 1.30 \\
\hline $\mathrm{SFM}_{7} \mathrm{E}_{0}$ & 4.91 & 3.71 & 12.77 & 5.53 & 24.57 & 17.19 & 1.44 \\
\hline $\mathrm{SFM}_{7} \mathrm{E}+$ & 4.92 & 3.62 & 12.58 & 5.23 & 23.72 & 15.68 & 1.27 \\
\hline $\mathrm{SFM}_{14} \mathrm{E}_{0}$ & 4.76 & 3.45 & 10.51 & 5.43 & 22.74 & 15.02 & 1.29 \\
\hline $\mathrm{SFM}_{14} \mathrm{E}+$ & 4.98 & 3.52 & 11.77 & 5.23 & 21.36 & 15.44 & 1.22 \\
\hline $\mathrm{SFM}_{21} \mathrm{E}_{0}$ & 4.93 & 3.58 & 10.79 & 5.54 & 22.74 & 16.77 & 1.33 \\
\hline $\mathrm{SFM}_{21} \mathrm{E}+$ & 4.87 & 3.61 & 10.45 & 5.26 & 21.88 & 16.32 & 1.23 \\
\hline $\mathrm{SEM}^{2}$ & 0.056 & 0.052 & 0.717 & 0.077 & 0.393 & 0.277 & 0.020 \\
\hline \multicolumn{8}{|l|}{ Diet (D) } \\
\hline $\mathrm{SFM}_{0}$ & 4.92 & 3.81 & 13.08 & 5.48 & $24.13^{a}$ & 16.12 & 1.34 \\
\hline $\mathrm{SFM}_{7}$ & 4.91 & 3.67 & 12.68 & 5.38 & $24.15^{\mathrm{a}}$ & 16.44 & 1.36 \\
\hline $\mathrm{SFM}_{14}$ & 4.87 & 3.49 & 11.14 & 5.33 & $22.05^{b}$ & 15.23 & 1.26 \\
\hline $\mathrm{SFM}_{21}$ & 4.90 & 3.60 & 10.62 & 5.40 & $22.31^{\mathrm{b}}$ & 16.55 & 1.28 \\
\hline P value & 0.505 & 0.064 & 0.089 & 0.509 & $<0.05$ & 0.324 & 0.143 \\
\hline \multicolumn{8}{|c|}{ Enzymes mixtures $(E)$} \\
\hline $\mathrm{E}_{0}$ & 4.87 & 3.63 & 11.87 & 5.53 & 23.66 & 16.17 & 1.36 \\
\hline $\mathrm{E}+$ & 4.93 & 3.65 & 11.89 & 5.26 & 22.67 & 16.00 & 1.26 \\
\hline P value & 0.145 & 0.386 & 0.768 & 0.345 & 0.193 & 0.705 & 0.099 \\
\hline Interaction $\mathrm{D} \times \mathrm{E}$ & 0.295 & 0.677 & 0.479 & 0.799 & 0.966 & 0.126 & 0.525 \\
\hline
\end{tabular}

' $\mathrm{SFM}$ was applied at following dietary levels: $0,7,14$ and $21 \%\left(\mathrm{SFM}_{0}, \mathrm{SFM}_{7}, \mathrm{SFM}_{14}\right.$ and $\mathrm{SFM}_{21}$ respectively); ${ }^{2} \mathrm{SEM}$ - standard error of the mean (SD for all birds divided by the square root of turkey number); values within each column with the same superscript letter are not different at $\mathrm{P} \leq 0.05$ 
After 8 weeks of experimental feeding, the lowest caecal tissue mass was found in turkeys fed the diet with highest SFM content $\left(\mathrm{SFM}_{21}<\mathrm{SFM}_{0}\right.$ and $\mathrm{SFM}_{7}$; $\mathrm{P}<0.05$; Table 4). The mass of the caecal digesta was noted to be the highest in the control treatment and was decreasing as follows: $\mathrm{SFM}_{0}{ }^{a}>\mathrm{SFM}_{7}{ }^{b}>\mathrm{SFM}_{14}{ }^{c}>$ $\mathrm{SFM}_{21}{ }^{c}$. The low dietary level of SFM (7\%) elicited a significant increase in caecal dry matter concentration as compared to the other groups $(\mathrm{P}<0.05)$. The caecal ammonia concentration as well as colonic $\mathrm{pH}$ and tissue mass were not affected by the dietary treatments, either by SFM or enzyme preparation addition. The dietary application of the NSP-degrading enzymes mixture resulted in a significant increase in the $\mathrm{pH}$ of caecal digesta $\left(\mathrm{E}+>\mathrm{E}_{0} ; \mathrm{P}<0.05\right)$. The activity of bacterial $\beta$-glucosidase and $\beta$-glucuronidase was not affected by the level of dietary SFM or the application of exogenous enzymes (Table 5). On the other hand, both main

Table 4. Indices of lower GIT functioning in turkeys fed diets with increasing levels of sunflower meal' (SFM) without or with inclusion of feed enzymes (E)

\begin{tabular}{|c|c|c|c|c|c|c|c|}
\hline & \multicolumn{5}{|c|}{ Caeca } & \multicolumn{2}{|c|}{ Colon } \\
\hline & $\begin{array}{c}\mathrm{pH} \text { of } \\
\text { digesta }\end{array}$ & $\begin{array}{l}\text { tissue, } \\
\mathrm{g} / \mathrm{kg} \mathrm{BW}\end{array}$ & $\begin{array}{l}\text { digesta, } \\
\text { g/kg BW }\end{array}$ & $\begin{array}{c}\text { dry matter, } \\
\%\end{array}$ & $\begin{array}{c}\text { ammonia, } \\
\mathrm{mg} / \mathrm{g}\end{array}$ & $\begin{array}{c}\mathrm{pH} \text { of } \\
\text { digesta }\end{array}$ & $\begin{array}{c}\text { tissue, } \\
\mathrm{g} / \mathrm{kg} \mathrm{BW}\end{array}$ \\
\hline \multicolumn{8}{|l|}{ Subgroup } \\
\hline $\mathrm{SFM}_{0} \mathrm{E}_{0}$ & 5.93 & 4.59 & 4.71 & 15.68 & 0.73 & 4.92 & 3.56 \\
\hline $\mathrm{SFM}_{0} \mathrm{E}+$ & 5.91 & 4.38 & 4.79 & 15.82 & 0.70 & 4.90 & 3.48 \\
\hline $\mathrm{SFM}_{7} \mathrm{E}_{0}$ & 5.94 & 4.23 & 3.79 & 16.42 & 0.72 & 4.86 & 3.45 \\
\hline $\mathrm{SFM}_{7} \mathrm{E}+$ & 6.06 & 3.98 & 3.68 & 17.63 & 0.69 & 4.86 & 3.43 \\
\hline $\mathrm{SFM}_{14} \mathrm{E}_{0}$ & 5.78 & 3.94 & 2.23 & 15.44 & 0.71 & 4.84 & 3.59 \\
\hline $\mathrm{SFM}_{14} \mathrm{E}+$ & 6.16 & 3.83 & 2,06 & 15.59 & 0.68 & 4.79 & 3.53 \\
\hline $\mathrm{SFM}_{21} \mathrm{E}_{0}$ & 5.99 & 3.62 & 1.97 & 15.13 & 0.68 & 5.12 & 3.57 \\
\hline $\mathrm{SFM}_{21} \mathrm{E}+$ & 6.23 & 3.57 & 1.78 & 14.87 & 0.60 & 5.05 & 3.64 \\
\hline $\mathrm{SEM}^{2}$ & 0.062 & 0.084 & 0.249 & 0.426 & 0.039 & 0.073 & 0.072 \\
\hline \multicolumn{8}{|l|}{$\operatorname{Diet}(D)$} \\
\hline $\mathrm{SFM}_{0}$ & 5.92 & $4.49^{\mathrm{a}}$ & $4.75^{a}$ & $15.75^{\mathrm{b}}$ & 0.71 & 4.91 & 3.52 \\
\hline $\mathrm{SFM}_{7}$ & 6.00 & $4.11^{\mathrm{a}}$ & $3.74^{\mathrm{b}}$ & $17.03^{\mathrm{a}}$ & 0.71 & 4.86 & 3.44 \\
\hline $\mathrm{SFM}_{14}$ & 5.97 & $3.89^{\mathrm{ab}}$ & $2.15^{c}$ & $15.52^{\mathrm{b}}$ & 0.70 & 4.82 & 3.56 \\
\hline $\mathrm{SFM}_{21}$ & 6.11 & $3.60^{\mathrm{b}}$ & $1.88^{\mathrm{c}}$ & $15.00^{\mathrm{h}}$ & 0.64 & 5.08 & 3.61 \\
\hline P value & 0.756 & $<0.05$ & $<0.05$ & $<0.05$ & 0.310 & 0.232 & 0.666 \\
\hline \multicolumn{8}{|c|}{ Enzymes mixtures (E) } \\
\hline $\mathrm{E}_{0}$ & $5.91^{\mathrm{b}}$ & 4.09 & 3.18 & 15.67 & 0.71 & 4.94 & 3.54 \\
\hline $\mathrm{E}+$ & $6.09^{\mathrm{a}}$ & 3.94 & 3.08 & 15.98 & 0.67 & 4.90 & 3.52 \\
\hline P value & $<0.05$ & 0.314 & 0.789 & 0.291 & 0.407 & 0.945 & 0.742 \\
\hline Interaction $\mathrm{D} \times \mathrm{E}$ & 0.482 & 0.527 & 0.550 & 0.385 & 0.460 & 0.981 & 0.628 \\
\hline
\end{tabular}

'SFM was applied at following dietary levels: $0,7,14$ and $21 \%\left(\mathrm{SFM}_{0}, \mathrm{SFM}_{7}, \mathrm{SFM}_{14}\right.$, and $\mathrm{SFM}_{21}$, respectively); ${ }^{2}$ SEM, standard error of the mean (SD for all birds divided by the square root of turkey number); values within each column with the same superscript letter are not different at $\mathrm{P} \leq 0.05$ 
Table 5. Activity of bacterial enzymes in caecal digesta $(\mathrm{U} / \mathrm{g})$ of turkeys fed diets with increasing levels of sunflower meal' (SFM) without or with inclusion of feed enzymes (E)

\begin{tabular}{|c|c|c|c|c|c|}
\hline \multirow{2}{*}{ Dietary treatment } & \multicolumn{2}{|c|}{ Glucosidase } & \multicolumn{2}{|c|}{ Galactosidase } & \multirow{2}{*}{$\beta$-glucuronidase } \\
\hline & $\alpha-$ & $\beta-$ & $\alpha-$ & $\beta-$ & \\
\hline \multicolumn{6}{|l|}{ Subgroup } \\
\hline $\mathrm{SFM}_{0} \mathrm{E}_{0}$ & 0.17 & 0.06 & 0.46 & 0.74 & 0.27 \\
\hline $\mathrm{SFM}_{0} \mathrm{E}+$ & 0.22 & 0.06 & 0.66 & 1.46 & 0.21 \\
\hline $\mathrm{SFM}_{?} \mathrm{E}_{0}$ & 0.26 & 0.09 & 0.63 & 0.99 & 0.30 \\
\hline $\mathrm{SFM}_{7} \mathrm{E}+$ & 0.31 & 0.08 & 0.90 & 1.61 & 0.26 \\
\hline $\mathrm{SFM}_{14} \mathrm{E}_{0}$ & 0.24 & 0.06 & 0.54 & 0.79 & 0.32 \\
\hline $\mathrm{SFM}_{14} \mathrm{E}+$ & 0.31 & 0.06 & 0.71 & 0.95 & 0.27 \\
\hline $\mathrm{SFM}_{2 \mathrm{l}} \mathrm{E}_{0}$ & 0.21 & 0.05 & 0.31 & 0.68 & 0.32 \\
\hline $\mathrm{SFM}_{21} \mathrm{E}+$ & 0.21 & 0.05 & 0.32 & 0.74 & 0.26 \\
\hline $\mathrm{SEM}^{2}$ & 0.009 & 0.007 & 0.030 & 0.062 & 0.023 \\
\hline \multicolumn{6}{|l|}{$\operatorname{Diet}(D)$} \\
\hline SFM $_{0}$ & $0.19^{\mathrm{b}}$ & 0.06 & $0.56^{\mathrm{h}}$ & $1.10^{\mathrm{a}}$ & 0.24 \\
\hline $\mathrm{SFM}_{7}$ & $0.29^{a}$ & 0.08 & $0.77^{\mathrm{a}}$ & $1.30^{\mathrm{a}}$ & 0.28 \\
\hline $\mathrm{SFM}_{14}$ & $0.27^{\mathrm{a}}$ & 0.06 & $0.63^{\mathrm{b}}$ & $0.87^{\mathrm{ab}}$ & 0.30 \\
\hline $\mathrm{SFM}_{21}$ & $0.21^{\mathrm{b}}$ & 0.05 & $0.32^{\mathrm{c}}$ & $0.71^{\mathrm{b}}$ & 0.29 \\
\hline P value & $<0.05$ & 0.417 & $<0.05$ & $<0.05$ & 0.843 \\
\hline \multicolumn{6}{|c|}{ Enzymes mixtures (E) } \\
\hline $\mathrm{E}_{0}$ & $0.22^{\mathrm{b}}$ & 0.07 & $0.49^{b}$ & $0.80^{\mathrm{b}}$ & 0.30 \\
\hline $\mathrm{E}+$ & $0.26^{\mathrm{a}}$ & 0.06 & $0.65^{a}$ & $1.19^{\mathrm{a}}$ & 0.25 \\
\hline$P$ value & $<0.05$ & 0.801 & $<0.05$ & $<0.05$ & 0.307 \\
\hline Interaction $\mathrm{D} \times \mathrm{E}$ & 0.341 & 0.995 & 0.129 & 0.111 & 0.998 \\
\hline
\end{tabular}

'SFM was applice at following dietary levels: $0,7,14$ and $21 \%\left(\mathrm{SFM}_{0}, \mathrm{SFM}_{7}, \mathrm{SFM}_{14}\right.$ and $\mathrm{SFM}_{21}$, respectively); ${ }^{2}$ SEM - standard error of the mean (SD for all birds divided by the square root of turkey number); values within each column with the same superscript letter are not different at $\mathrm{P} \leq 0.05$

enzymes (Table 5). On the other hand, both main experimental factors (SFM and enzyme preparation) significantly influenced the activities of bacterial $\alpha$-glucosidase, $\alpha$-galactosidase and $\beta$-galactosidase in the caecal digesta. When the level of SFM in a diet was taken into account, the highest activity of $\alpha$-glucosidase was observed in turkeys fed diets with low and moderate SFM content $\left(\mathrm{SFM}_{7}, \mathrm{SFM}_{14}>\mathrm{SFM}_{0}, \mathrm{SFM}_{21} ; \mathrm{P}<0.05\right)$. The birds from the $\mathrm{SFM}_{7}$ and $\mathrm{SFM}_{21}$ groups displayed the highest and the lowest $\alpha$-galactosidase activity, respectively (in both cases $\mathbf{P}<0.05$ vs other treatments). The $\mathrm{SFM}_{21}$ group was also characterized by the lowest $\beta$-galactosidase activity $\left(\mathrm{P}<0.05\right.$ vs $\mathrm{SFM}_{0}$ and $\mathrm{SFM}_{7}$ groups). The supplementation of diets with the NSP-degrading 
enzyme preparation resulted in enhanced activities of bacterial $\alpha$-glucosidase, $\alpha$-galactosidase and $\beta$-galactosidase in the caecal digesta of the turkeys $(\mathbf{P}<0.05)$. Regardless the addition of the NSP-degrading enzyme preparation, the increased SFM content in a diet up to $14-21 \%$ caused a significant decrease in the total concentration as well as content (pool) of VFA in the caeca in comparison to the control and $\mathrm{SFM}_{7}$ treatments (Table 6). It was mainly due to the enhanced concentration of acetic acid and - to a lower extent - of valeric acids $\left(\mathrm{SFM}_{0}\right.$ and $\mathrm{SFM}_{7}$ vs $\mathrm{SFM}_{14}$ and $\mathrm{SFM}_{21}$ groups; $\mathrm{P}<0.05$ ). Moreover, the $\mathrm{SFM}_{7}$ treatment was accompanied by the highest caecal propionate concentration as compared with the other groups $(\mathrm{P}<0.05)$. When the enzyme preparation applied

Table 6. Concentration ( $\mu \mathrm{mol} / \mathrm{g}$ fresh digesta), total content ( $\mu \mathrm{mol} / \mathrm{kg}$ body weight) of volatile fatty acids (VFA) in the caeca of turkeys fed experimental diets

\begin{tabular}{|c|c|c|c|c|c|c|c|c|}
\hline $\begin{array}{l}\text { Subgroup, } \\
\text { Treatments }\end{array}$ & $\begin{array}{l}\text { Total } \\
\text { VFA }\end{array}$ & $\mathrm{C} 2$ & C3 & $\mathrm{C} 4 \mathrm{i}$ & $\mathrm{C} 4$ & $\mathrm{C} 5 \mathrm{i}$ & C5 & $\begin{array}{l}\text { VFA } \\
\text { pool }\end{array}$ \\
\hline \multicolumn{9}{|l|}{ Subgroup } \\
\hline $\mathrm{SFM}_{t 0} \mathrm{E}_{0}$ & 133 & $84.0^{\mathrm{a}}$ & $10.6^{\mathrm{c}}$ & 1.71 & 31.3 & 1.45 & 4.07 & 627 \\
\hline $\mathrm{SFM}_{0} \mathrm{E}+$ & 120 & $69.8^{b}$ & $13.9^{\mathrm{c}}$ & 1.87 & 27.2 & 2.37 & 4.93 & 574 \\
\hline $\mathrm{SFM}_{7} \mathrm{E}_{0}$ & 140 & $80.6^{\mathrm{a}}$ & $22.8^{a}$ & 1.76 & 27.4 & 2.10 & 5.68 & 531 \\
\hline $\mathrm{SFM}_{7} \mathrm{E}+$ & 131 & $78.7^{\mathrm{ab}}$ & $17.8^{\mathrm{b}}$ & 1.85 & 25.9 & 2.28 & 4.73 & 182 \\
\hline $\mathrm{SFM}_{14} \mathrm{E}_{0}$ & 121 & $71.5^{\mathrm{ab}}$ & $14.5^{\mathrm{bc}}$ & 1.63 & 27.7 & 1.71 & 4.36 & 270 \\
\hline $\mathrm{SFM}_{14} \mathrm{E}+$ & 104 & $64.5^{b}$ & $12.4^{c}$ & 1.35 & 21.6 & 1.73 & 2.87 & 214 \\
\hline $\mathrm{SFM}_{21} \mathrm{E}_{0}$ & 111 & $66.9^{\mathrm{b}}$ & $13.1^{\circ}$ & 1.64 & 24.5 & 1.65 & 3.11 & 219 \\
\hline $\mathrm{SFM}_{21} \mathrm{E}+$ & 115 & $71.3^{\mathrm{ab}}$ & $13.0^{\mathrm{c}}$ & 1.63 & 23.8 & 2.06 & 2.85 & 205 \\
\hline $\mathrm{SEM}^{2}$ & 2.342 & 1.510 & 0.630 & 0.073 & 0.853 & 0.098 & 0.211 & 29.25 \\
\hline \multicolumn{9}{|l|}{ Diet (D) } \\
\hline $\mathrm{SFM}_{0}$ & $127^{\mathrm{a}}$ & $76.9^{a}$ & $12.3^{b}$ & 1.79 & 29.3 & 1.91 & $4.50^{\mathrm{a}}$ & $601^{a}$ \\
\hline $\mathrm{SFM}_{7}$ & $136^{\mathrm{a}}$ & $79.7^{a}$ & $20.3^{\mathrm{a}}$ & 1.81 & 26.7 & 2.17 & $5.21^{\mathrm{a}}$ & $507^{a}$ \\
\hline $\mathrm{SFM}_{14}$ & $113^{\mathrm{b}}$ & $68.0^{\mathrm{b}}$ & $13.5^{\mathrm{b}}$ & 1.49 & 24.7 & 1.72 & $3.62^{\mathrm{h}}$ & $242^{\mathrm{b}}$ \\
\hline $\mathrm{SFM}_{21}$ & $113^{b}$ & $69.1^{\mathrm{b}}$ & $13.1^{\mathrm{b}}$ & 1.64 & 24.2 & 1.86 & $2.98^{b}$ & $212^{b}$ \\
\hline$P$ value & $<0.05$ & $<0.05$ & $<0.05$ & 0.386 & 0.330 & 0.079 & $<0.05$ & $<0.05$ \\
\hline \multicolumn{9}{|c|}{ Enzymes mixtures (E) } \\
\hline $\mathrm{E}_{0}$ & $126^{\mathrm{a}}$ & 75.8 & 15.3 & 1.69 & $27.7^{\mathrm{a}}$ & $1.73^{\mathrm{b}}$ & 4.31 & 412 \\
\hline E+ & $118^{b}$ & 71.1 & 14.3 & 1.68 & $24.6^{\mathrm{b}}$ & $2.11^{\mathrm{a}}$ & 3.85 & 369 \\
\hline Pvalue & $<0.05$ & 0.663 & 0.663 & 0.982 & $<0.05$ & $<0.05$ & 0.284 & 0.242 \\
\hline Interaction $\mathrm{D} \times \mathrm{E}$ & 0.173 & $<0.05$ & $<0.05$ & 0.699 & 0.474 & 0.076 & 0.061 & 0.944 \\
\hline
\end{tabular}

' SFM was applied at following dietary levels: $0,7,14$ and $21 \%\left(\mathrm{SFM}_{0}, \mathrm{SFM}_{7}, \mathrm{SFM}_{14}\right.$ and $\mathrm{SFM}_{21}$, respectively); ${ }^{2} \mathrm{SEM}$ - standard error of the mean (SD for all birds divided by the square root of turkey number); values within each column with the same superscript letter are not different at $\mathrm{P} \leq 0.05$ 
to a diet was taken into consideration, the E+ treatment caused a significant decrease in the total VFA and butyric acid as well as an increase in isovaleric acid concentrations ( $\mathrm{P}<0.05$ vs $\mathrm{E}_{0}$ treatment). An interaction between $S F M$ content and enzymatic supplementation affected the caecal concentrations of acetic and propionic acids. In contrast to the control treatment, the addition of enzymes to diets with a low $(7 \%)$, moderate $(14 \%)$ and high $(21 \%)$ sunflower meal content did not affect $\mathrm{C}_{2}$ caecal concentration significantly $(\mathrm{P}<0.05)$. The concentration of this acid in the $\mathrm{SFM}_{0} \mathrm{E}_{0}$ subgroup was significantly higher than in the birds fed the $\mathrm{SFM}_{0} \mathrm{E}+$ diet. Alike differences were noted between subgroups $\mathrm{SFM}_{7} \mathrm{E}_{0}$ and $\mathrm{SFM}_{7} \mathrm{E}+$ with regard to the concentration of caecal propionic acid.

\section{DISCUSSION}

At the termination of the performance part of this study we observed that the body weight $(\mathrm{BW})$ of 8 -wk turkeys fed diets with a relatively high sunflower meal (SFM) content may be depressed in comparison to the BW of control birds receiving the soyabean meal-based diet. Therefore, a special attention was paid to the gastrointestinal tract response of growing turkeys fed diets with different contents of SFM added at the expense of soyabean meal and partly of wheat. The efficacy of NSP-degrading enzymes application was assessed as well.

As for the applied enzyme supplementation, the data obtained revealed that the enzymatic mixture added to a diet caused a tendency towards lower ileal viscosity $(\mathrm{P}=0.099)$ and a significant decrease in caccal total volatile fatty acids (VFA) concentration, despite an increase in the activities of bacterial $\alpha$-glucosidase, $\alpha$-galactosidase and $\beta$-galactosidase observed in the $\mathrm{E}+$ treatment. The decrease in VFA concentration was probably the main reason for an increase in caecal $\mathrm{pH}$ value observed in E-supplemented treatment. The minor effect of the enzyme preparation on ileal viscosity was in accordance with a relatively small content of soluble NSP in experimental diets. It should be emphasized, however, that the viscosity values observed in the current study were relatively low (1.22-1.44 $\mathrm{mPa} \cdot \mathrm{s}$ ) and lower than the values of 3.0 to $5.0 \mathrm{mPa} \cdot \mathrm{s}$ observed in broiler chickens and growing turkeys fed wheat-based diets (Juśkiewicz et al., 2005; Meng et al., 2005). Furthermore, such low intestinal viscosity values have been reported to have a minimal, if any, effect on growth performance of broilers (Liang and Liu, 1988).

Following the increasing dietary level of SFM in a diet, a considerable decrease in relative tissue mass of ventriculus, small intestine, and caeca, expressed as a percentage of $\mathrm{BW}$, was observed after 8 weeks of feeding in turkeys exposed to the higher doses of SFM. It is common knowledge that it is not only the level 
of dietary fibre that is of paramount importance for gastrointestinal tract (GIT) segments development, but the type or the source of fibre also plays a significant role in digestion and absorption (Wenk, 2001). In comparison to soyabean meal, sunflower meal used in this study contained more total NSP (27.0 vs $17.9 \%)$, more lignin ( 8.6 vs $0.5 \%$ ), and more crude fibre ( 15.3 vs $4.8 \%$ ). SBM exceeded SFM only in respect of the content of water-soluble NSP (1.05 vs $0.78 \%$ ). Therefore, diets with SFM were characterized by an increasing level of crude fibre, lignin and total NSP, but a lower content of water-soluble NSP (Table 1). Our findings are in contradiction with the suggestion made by Dusterhoft et al. (1992) that the presence in the sunflower seeds of a substantial amount of cell-wall material, mainly cellulose, pectic polysaccharides and 4-0-methyl-glucuroxylans, with small amounts of glucomannans and fucoxyloglucans, could exert a trophic effect on the intestinal mucosa, increasing the intestinal size. Other authors reported a different response of intestinal organs to sunflower products. Arija et al. (2000) showed the shortening and thickening of the jejunal villi caused by the inclusion of full-fat sunflower kernels in chicken diets. In turn, Brenes et al. (2008) observed a decrease in the size of the small intestine (particularly the duodenum) and caeca in chickens fed $15 \%$ high oleic acid sunflower seeds. One explanation to the lower weight of GIT segments, observed in our study, could be faster passage of digesta through the gastrointestinal tract in the SFMfed birds, as supported by the significantly decreased digesta mass in the caeca. Another reason for the foregoing effect might be the lower content of soluble polysaccharides in diets containing sunflower meal in comparison to the control SBM-containing diet. It is well established that water-soluble polysaccharides may evoke a considerable increase in the weight of caecal tissue and digesta in monogastric animals, in a big part due to an increased bacterial number and greater fermentation in the lower parts of GIT (Juśkiewicz and Zduńczyk, 2004). Some researchers reported that a diet supplementation with non-digestible carbohydrate fractions may result in an enhanced glycolytic activity of microorganisms living in the large intestines of monogastric animals (Monsan and Paul, 1995). In our experiment, the highest activities of bacterial $\alpha$-glucosidase, $\alpha$-galactosidase and $\beta$-galactosidase were observed when $\mathrm{SFM}_{7}$ treatment was applied. $\beta$-galactosidase, $\alpha$-galactosidase and $\alpha$-glucosidase activities can improve the fermentation of lactose, raffinose family oligosaccharides and resistant starch, leading to VFA and lactic acids which are the source of energy for the tissues. However, the activities of potentially-harmful $\beta$-glucuronidase and $\beta$-glucosidase were similar in all groups, which should be considered as a positive effect of sunflower meal addition to a diet for turkeys. Both $\beta$-glucuronidase and $\beta$-glucosidase have been implicated in the generation 
of mutagens or carcinogens in the hindgut (Campbell et al., 1997). It could be assumed that well-balanced content of dietary insoluble and soluble non-digestible carbohydrates may positively affect the activity of enzymatic microbiota.

When large amounts of fermentable carbohydrates were fed, the increased caeca weights (especially tissue) were considered as a positive physiological response associated with some beneficial changes in the large intestine, e.g., acidification of digesta, increased VFA contents (Jankowski et al., 2009). In the present study, the application of diets containing increasing levels of SFM was indeed in reverse relation to VFA concentration and pool. In the presence of different fermentable carbohydrates, the VFA pool size rather than the individual fatty acid concentration has been postulated to be the best indicator of the intensity of colonic fermentation (Campbell et al., 1997). In the 8-wk-old turkeys, the VFA pool in the birds fed the $\mathrm{SFM}_{14}$ and $\mathrm{SFM}_{21}$ treatments was more than $2+$ fold lower than that of the birds fed the $\mathrm{SFM}_{7}$ and $\mathrm{SFM}_{0}$ diets. Our recent study on growing turkeys demonstrated that, in contrast to dietary crude fibre applied at the doses of 3.5 or $5.3 \%$, the different dietary level of soyabean $\alpha$-gactosides $(0.06,0.93,1.69$ and $2.33 \%$ ) caused a distinct response of turkeys caeca (Zduńczyk et al., in press). In that study we concluded that soyabean raffinose-family oligosaccharides seemed to greatly affect the development and physiology of the GIT, and that their presence in the amount of approximately $1 \%$ in a diet for growing turkeys ought to be considered as nutritionally advisable. The present experiment proved that sunflower meal added at the level of 14 or $21 \%$ to a diet delivered excessive amounts of crude fibre, lignin, and water-insoluble non-starch polysaccharides, which in turn inhibited the fermentation processes in the caeca and, to some extent, impaired the development of the upper GIT segments in growing turkeys.

\section{CONCLUSIONS}

In conclusion, sunflower meal (SFM) rich in crude fibre and lignin added at the level of $14-21 \%$ to a diet for growing turkeys may induce undesirable processes in the gastrointestinal tract development manifested in decreased relative mass of small intestine and caecal tissues, as well as in potent inhibition of the fermentation processes in the caeca. Having in mind a worsening in birds' growth observed during the performance stage of the study, it should be concluded that the dietary SFM level at $14 \%$ and more seems to be an overdose for young growing turkeys. On the other hand, our study showed also that high fibre SFM could be an effective alternative substitute of soyabean meal for growing turkeys when applied at the dietary level of up to $7 \%$. 


\section{REFERENCES}

AOAC, 2005. Association of the Official Analytical Chemists, Official Methods of Analysis. $18^{\text {th }}$ Edition. Arlington, VA

Arija 1., Viveros A., Brenes A., Canales R., Pizarro M., Castano M., 2000. Histological alterations in the intestinal epithelium caused by the inclusion of full-fat sunflower kernels in broiler chicken diets. Poultry Sci. 79, 1332-1334

Bach Knudsen K.E., 2001. The nutritional significance of "dietary fibre" analysis. Anim. Feed Sci. Tech. 90, 3-20

Brenes A., Centeno C., Viveros A., Arija I., 2008. Effect of enzyme addition on the nutritive value of high oleic acid sunflower seeds in chicken diets. Poultry Sci. 87, 2300-2310

Campbell J.M., Fahey Jr. G.C., Wolf B.W., 1997. Selected indigestible oligosaccharides affect large bowel mass, cecal and fecal short-chain fatty acids, $\mathrm{pH}$ and microflora in rats. J. Nutr. 127, 130136

Dusterhoft E.M., Posthumus M.A., Voragen A.G.J., 1992. Non-starch polysaccharide from sunflower (Helianthus Annuus) meal and palm-kernel (Elaeis guineensis) meal. II. Investigation of the structure of major polysaccharides. J. Sci. Food Agr. 59, 151-160

Hofirek B., Haas D., 2001. Comparative studies of ruminal fluid collected by oral tube or by puncture of the caudorental ruminal sac. Acta Vet. Brno 70, 27-33

Jankowski J., Juśkiewicz J., Gulewicz K., Lecewicz A., Slominski B.A., Zduńczyk Z., 2009. The effect of diets containing soybean meal, soybean protein concentrate, and soybean protein isolate of different oligosaccharide content on growth performance and gut function of young turkeys. Poultry Sci. 88, 2132-2140

Juśkicwicz J., Jankowski J., Zduńczyk Z., Lecewicz A., Przybylska-Gornowicz B., Zięba M., 2009. Effect of diets with different contents of soybean $\alpha$-galactosides and crude fibre on modification of duodenal microstructure and selected parametrs of nutrient utilization in young turkeys. Pol. J. Vet. Sci. $12,455-463$

Juśkiewicz J., Jankowski J., Zduńczyk Z., Mikulski D., 2006. Performance and gastrointestinal tract metabolism of turkeys fed diets with different content of fructooligosaccharide. Poultry Sci. 85, 886-891

Juśkiewicz J., Mikulski D., Jankowski J., Zduńczyk Z., 2005. Gastrointestinal responses of turkeys to the addition of exogenous xylanase and glucanase to diets. J. Anim. Feed Sci. 14, Suppl. 1, $451-454$

Juśkiewicz J., Zduńczyk Z., 2004. Effects of cellulose, carboxymethylcellulose and inulin fed to rats as single supplements or in combinations on their caecal parameters. Comp. Biochem. Physiol. Pt. A 139, 513-519

Liang C., Liu Y., 1988. AME examined in relation to wheat-fed broilers. Feedstuffs 60 (5), 12-15

Meng X., Slominski B.A., Nyachoti M., Campbell L.D., Guenter W., 2005. Degradation of cell wall polysaccharides by combinations of carbohydrase enzymes and their effect on nutrient utilization and broiler chicken performance. Poultry Sci. 84, 37-47

Monsan P.F., Paul F., 1995. Oligosaccharide feed additives. In: R.J. Wallace, A. Chesson (Editors). Biotechnology in Animal Feeds and Feeding. Weinheim and New York: VCH Verlagsgesellschaft mBH, pp. 233-245

Musthaq T., Sarwar M., Ahmad G., Nisa M.U., Jamil A., 2006. The influence of exogenous multienzyme preparation and graded levels of digestible lysine in sunflower meal-based diets on the performance of young broiler chicks two weeks posthatching. Poultry Sci. 85, 2180-2185

NRC, 1994. Nutrient Requirements of Poultry. National Research Council. 9 ${ }^{\text {th }}$ Edition. National Academy Press. Washington, DC 
Slominski B.A., Campbell L.D., 1990. Non-starch polysaccharides of canola meal: Quantification, digestibility in poultry and potential benefit of dietary enzyme supplementation. J. Sci. Food Agr. 53, 175-184

Snedecor G.W., Cochran W.G., 1989. Statistical Methods. $8^{\text {th }}$ Edition. Ames, Iowa (USA)

Stodolak B., Starzyńska-Janiszewska A., Pustkowiak H., Mickowska B., 2009. Effect of sunflower seeds addition on the nutritional value of grass pea tempeh. Pol. J. Food Nutr. Sci. 59, 145-150

Vieira S.L., Penz Jr. A.M., Leboute E.M., Corteline J., 1992. A nutritional evaluation of a high fiber sunflower meal. J. Appl. Poultry Res. 1, 382-388

Wenk C., 200I. The role of dietary fibre in the digestive physiology of the pig. Anim. Feed Sci. Tech. $90,21-33$

Zduńczyk Z., Jankowski J., Juśkiewicz J., Lecewicz A., Slominski B., (in press). Application of soybcan meal, soy protein concentrate and isolate differing in $\alpha$-galactosides content to lowand high-fibre diets in growing turkeys. J. Anim. Physiol. Anim. Nutr. (DOI: 10.1111/j.14390396.2009.00939) 